\title{
The Pharmacological Role and Clinical Applications of Antipsychotics' Active Metabolites: Paliperidone versus Risperidone
}

\author{
Cecilio Álamo ${ }^{1}$ and Francisco López-Muñoz ${ }^{1,2 *}$
}

${ }^{1}$ Department of Pharmacology, Faculty of Medicine, University of Alcalá, Madrid, Spain

${ }^{2}$ Faculty of Health Sciences, Camilo José Cela University, Madrid, Spain

\begin{abstract}
Some antipsychotic drugs are metabolized in the liver, leading to active metabolites. These metabolites can maintain the effect of the original substrate or display different pharmacokinetic or pharmacodynamic properties, and that can be translated by a different profile of responses and interactions to clinical level. Among these is risperidone, whose active metabolite, 9-OH-risperidone, is known as paliperidone and has been marketed as such. In this review, we analyze the differential pharmacological aspects between risperidone and paliperidone, both from the pharmacokinetic (bioavailability, effect of CYP450 and P-glycoprotein, etc.) and pharmacodynamic perspectives (affinity for dopaminergic and/or serotonergic receptors, speed of dissociation from dopamine receptors, serotonin $5-H_{2}$ receptor occupancy $>D_{2}$, etc.) as well as differential electrophysiological profile and neuroprotective role. The pharmacological differences between the two drugs could explain the differential clinical response exhibited by schizophrenic patients treated with both agents, as well as some differences in tolerability profile and drug interactions.
\end{abstract}

Keywords: Active metabolites; Antipsychotic drugs; Paliperidone; Risperidone; Schizophrenia

\section{Introduction}

The synthesis of chlorpromazine in December, 1950, and the recognition of its antipsychotic properties that followed in $1952[1,2]$, together with reserpine's introduction for clinical use in $1953[3,4]$, are two of the foundational events that together marked the so-called "psychopharmacological revolution." Next, Paul Janssen's discovery of haloperidol's antipsychotic properties in the late 1950s and its subsequent commercialization $[5,6]$ opened the door to a new world of hope in the treatment of psychosis, offering a selective, effective treatment for schizophrenic patients $[7,8]$. These options were a marked improvement from 'biological therapies', which were remedies that merely provided palliative and largely transient relief with dubious effectiveness [9].

In 1959, a Swiss company by the name of Wander selected a preparation with very specific pharmacological behavior from a series of tricyclic compounds. It did not cause catalepsy, did not influence apomorphine-induced stereotypes, and at high doses, it inhibited the escape reflex and arousal reactions through midbrain stimulation. This drug later came to be known as clozapine [10]. In light of that profile, despite several researchers' rejection of it, Jules Angst succeeded in clinically demonstrating that it was an effective antipsychotic with no extrapyramidal symptoms [11]. Paul Janssen argued that since it did not induce catalepsy, it could be considered a neuroleptic, but clinical results obliged him to admit that if clozapine was a neuroleptic at all, it was an "atypical antipsychotic" [12].

In an effort to improve upon haloperidol's pharmacological properties, Janssen discovered that pipamperone, an agent introduced in the year 1961, whose pharmacological and clinical profile was distinct from haloperidol and all other known antipsychotic drugs at the time, had considerable anti-tryptamine ability [13] and brought about resocializing effects [14]. While no connection was drawn at the time between that clinical feature and its antiserotonergic properties, some authors argue that pipamperone was the first atypical antipsychotic, albeit a premature one. In fact, when risperidone was created, Janssen suggested it was a more potent version of pipamperone. Synthesized in the year 1984, risperidone's pharmacological properties were similar to pipamperone's in that both block more serotonin than dopamine receptors; yet risperidone was three-hundred times more potent than pipamperone. Meanwhile, both drugs were stronger antagonists at those receptors than clozapine [5], which had been considered the gold standard of atypical antipsychotics. These findings laid the groundwork for the hypothesis that blocking serotonin $5-\mathrm{HT}_{2}$ receptors and to a lesser extent dopamine $\mathrm{D}_{2}$ receptors, is the source of atypical antipsychotic effects [15]. From a clinical standpoint, building on that hypothesis has yielded the best results. From it most new antipsychotic agents were developed, termed in the field as "second-generation", or more commonly "atypical", antipsychotics [7,16,17], these have included clozapine, risperidone, olanzapine, ziprasidone, sertindol, quetiapine, and asenapine, among others [18].

Yet the label "atypical" encompasses a group of antipsychotics that, despite belonging to the same therapeutic class and sharing certain pharmacodynamic features, are vastly different, clinically speaking. Pharmacological differences may influence how a drug's effects manifest themselves and how long they last, whether therapeutic or adverse. Most antipsychotics are metabolized by the liver, usually producing inactive metabolites. In some cases, however, antipsychotics' biotransformation can produce active metabolites capable of sustaining the original substrate's effects, or of taking on different pharmacokinetic or pharmacodynamic properties. This has been observed experimentally "in vitro" as well as "in vivo". This can translate to a different profile of responses and interactions, clinically speaking. Of the antipsychotics in which the active metabolites have been reported (Table 1), risperidone stands out; its active metabolite, 9-OH-risperidone, has been labeled and sold as paliperidone. The following review will refer to differential

*Corresponding author: Francisco López-Muñoz, Faculty of Health Sciences, Camilo José Cela University, C/Castillo de Alarcón, 49, Urb. Villafranca del Castillo, 28692 Villanueva de la Cañada, Madrid, Spain, E-mail: francisco.lopez.munoz@gmail.com

Received January 04, 2013; Accepted January 25, 2013; Published January 27 2013

Citation: Álamo C, López-Muñoz F (2013) The Pharmacological Role and Clinical Applications of Antipsychotics' Active Metabolites: Paliperidone versus Risperidone. Clin Exp Pharmacol 3: 117. doi:10.4172/2161-1459.1000117

Copyright: @ 2013 Álamo C, et al. This is an open-access article distributed under the terms of the Creative Commons Attribution License, which permits unrestricted use, distribution, and reproduction in any medium, provided the original author and source are credited. 


\begin{tabular}{|c|c|c|c|c|c|c|}
\hline & $\begin{array}{c}\text { Usual dose } \\
\text { mg/day } \\
\text { (maximal dose) }\end{array}$ & $\begin{array}{c}\mathbf{T}_{\max } \\
\mathbf{( h )}\end{array}$ & $\begin{array}{c}\mathbf{T}_{1 / 2} \\
\mathbf{( h )}\end{array}$ & $\begin{array}{c}\mathbf{V}_{\mathbf{d}} \\
(\mathbf{I / K g})\end{array}$ & $\begin{array}{c}\mathbf{F} \\
\mathbf{( \% )}\end{array}$ & $\begin{array}{c}\text { BPP } \\
\mathbf{( \% )}\end{array}$ \\
\hline Haloperidol & $2-30(100)$ & $3-6$ & $15-30$ & $15-20$ & $40-80$ & $90-94$ \\
\hline Clozapine & $150-450(900)$ & $1-6$ & $12-36$ & $4-8$ & $40-60$ & 97 \\
\hline Risperidone & $\mathbf{4 - 1 6 ( 1 6 )}$ & $\mathbf{2}$ & $\mathbf{2 , 8}$ & $\mathbf{1 - 1 , 5}$ & $\mathbf{6 6 - 8 2}$ & $\mathbf{8 9}$ \\
\hline Olanzapine & $10-30(20)$ & $5-8$ & 33 & $10-20$ & $60-80$ & 93 \\
\hline Quetiapine & $150-750(800)$ & $1-1,5$ & $5,8-6,6$ & 10 & 100 & 83 \\
\hline Ziprasidone & $80-160$ & $3,8-5,2$ & $3,2-10$ & 1,5 & 60 & $>99$ \\
\hline Amisulpride & $400-1200(1200)$ & $1,5-4$ & 12 & 5,8 & 48 & 16 \\
\hline Aripiprazole & $10-30(30)$ & $3-5$ & $75-94$ & 4,9 & 87 & 99 \\
\hline Paliperidone & $\mathbf{3 - 1 2 ( 1 5 )}$ & $\mathbf{1 , 5}$ & $\mathbf{2 4 , 8}$ & $\mathbf{6 , 9}$ & $\mathbf{2 8}$ & $\mathbf{7 4}$ \\
\hline
\end{tabular}

$\mathrm{F}$ (Bioavailability); BPP (Binding plasmatic proteins).

Table 1: Pharmacokinetics of paliperidone vs. other atypical antipsychotic drugs and haloperidol.

characteristics of two antipsychotics: the original risperidone and its active metabolite, paliperidone.

\section{9-OH-Risperidone, the Active Metabolite in Risperidone}

Risperidone is metabolized primarily by cytochrome P450-2D6 (CYP2D6), giving way through hydroxylation to the active metabolite 9-OH-risperidone (Figure 1). Administering paliperidone, meanwhile, there is no conversion into risperidone. Early studies suggested that the actions of risperidone and its primary metabolite, 9-OH-risperidone, were pharmacologically similar, and that by administering risperidone, pharmacological activity could be attributed to the total plasma concentrations of risperidone and 9-OH-risperidone together.

Similarly, risperidone and 9-OH-risperidone are considered to have similar pharmacological activity, so presumably, the two together explain risperidone's antipsychotic component [20]. In fact, it was postulated that modifying the activity of CYP2D6 could alter the relationship between substrate and metabolite without altering overall pharmacological response, given that a decrease in 9-OH-risperidone cancels out any corresponding increase in risperidone. Applying that criterion, the presence of genetic polymorphism from CYP2D6, or of an enzyme inhibitor or inductor, is irrelevant to the final clinical outcome [21,22].

To date, several articles have demonstrated that risperidone and 9-OH-risperidone have neither the same therapeutic, pharmacological potency, nor the same toxicological activity [23]. When risperidone is administered, the results are a direct effect of that molecule as well as effects deriving from its active metabolite, 9-OH-risperidone. Bear in mind that most patients who take risperidone orally exhibit plasma levels of 9-OH-risperidone between 5 and 10 times higher than their plasma levels of risperidone [23].

We believe that simple fact is key to clinical practice; risperidone's pharmacokinetic and pharmacodynamic differences from paliperidone, which will be elaborated on in this paper, are considerable and warrant discussion. Yet as some authors argue [24], in other ways, the two agents behave similarly, both qualitatively and quantitatively.

From 9-OH-risperidone (risperidone's metabolite) to paliperidone: A different pharmacological entity

Strictly speaking, paliperidone (9-OH-risperidone) is the primary active metabolite in risperidone, having been hydroxylated at position 9 during the first phase of metabolism in the liver. This step is catalyzed mainly by isoenzyme CYP2D6, and to a lesser extent by CYP3A4 [25] (Figure 1).
Nowadays, paliperidone is considered an atypical antipsychotic belonging to the chemical family of benzisoxazole derivatives, whose molecular formula is $\mathrm{C}_{23} \mathrm{H}_{27} \mathrm{FN}_{4} \mathrm{O}_{3}$ and whose molecular weight is 426.49. Paliperidone is a racemic mixture of two enantiomers of similar potency.

Paliperidone was approved in the form of extended-release (Paliperidone ER) tablets by the Food and Drug Administration (FDA) on December 19, 2006 as a new therapeutic agent to treat schizophrenia under the commercial name Invega. According to the FDA's statement, it is a new molecular entity containing an active substance never before approved for commercial use in any form in the United States (Drugs@FDA, 2006). The European Commission, meanwhile, authorized the medication Invega as valid for commercial use in the entire European Union, favoring Janssen-Cilag International NV, on June 25, 2007 (Invega European Public Assessment Report. Scientific discussion, 2007). Next, the World Health Organization (WHO) deemed paliperidone (ATC N05AX13) distinct from other antipsychotics, specifically risperidone (ATC N05AX08) (The WHO Collaborating Centre for Drug Statistics Methodology ATC/DDD, 2007).

Paliperidone ER is the first oral antipsychotic to utilize the osmotic system, known as OROS (Oral Osmotic System) (Alza Corporation, Mountain View, California) or Push-Pull ${ }^{\mathrm{TM}}$ that can control the how fast paliperidone is released [26,27]. The osmotic formulation of paliperidone ER results for plasma profile with fewer oscillations than risperidone (Figure 2).

\section{Paliperidone Er's Differential Pharmacokinetic Profile As Compared To Oral Risperidone}

Table 1 details the main pharmacokinetic features of paliperidone ER, comparing them to risperidone and other atypical antipsychotics, and to haloperidol as a point of reference for classical neuroleptics.

\section{Absorption}

Generally speaking, antipsychotic medications are highly liposoluble, which explains their good, though not total, absorption through the digestive tract following oral ingestion, and volume of distribution $\left(\mathrm{V}_{\mathrm{d}}\right)$ (Table 1). In addition, in passing through the liver,

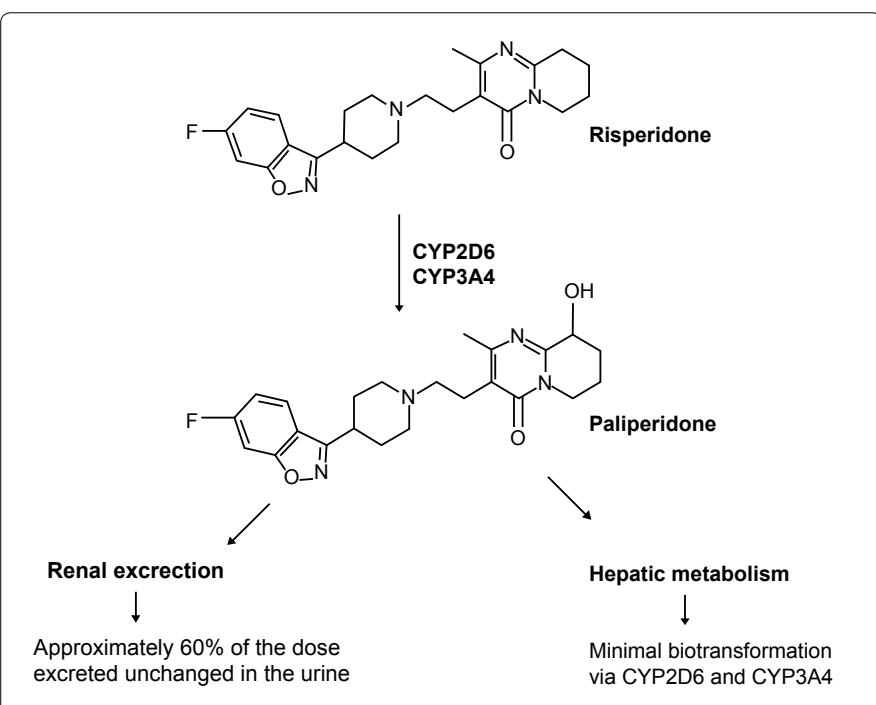

Figure 1: Metabolism and elimination of risperidone and paliperidone. Modified from Spina and Cavallaro [19]. 


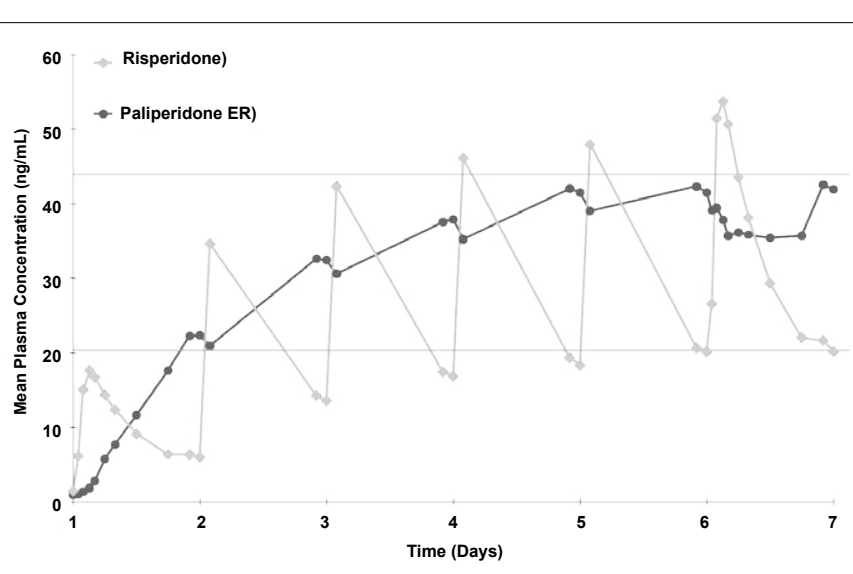

Figure 2: Pharmacokinetic profile of paliperidone ER and risperidone: mean plasma concentration vs. time. Modified from Pani et al. [28], and Kapur et al. [29].

they usually undergo what is termed the first-pass effect, which causes their bioavailability to decline, but this varies widely depending on the antipsychotic (from $10 \%$ to $80 \%$ ) [30].

One of the pharmacokinetic objectives of paliperidone ER is to achieve steady plasma levels with one daily dose. In other words, the aim is to have little fluctuation between peaks and troughs to minimize the occurrence of the adverse effects often linked to elevated levels of the primary active metabolite (Figure 2). Paliperidone in the form of ER tablets is pharmacokinetically linear within the recommended 3 to $12 \mathrm{mg}$ dose interval. The area under the curve is proportional to the administered dose and $\mathrm{T}_{\text {max }}$ (time it takes to reach the highest plasma concentration of the drug) and falls within the 20 to 25-hour range for all once-daily doses [31].

In one study, healthy research volunteers $(n=4)$ were administered one $6 \mathrm{mg}$ dose of paliperidone ER. On average, their highest plasma concentration $\left(\mathrm{C}_{\max }\right)$ was $11.7 \mathrm{ng} / \mathrm{mL}$, the time it took to reach that maximum concentration was 25.1 hours, and their $\mathrm{ABC}$ from 0 to 48 hours was $302 \mathrm{ng} \cdot \mathrm{h} / \mathrm{mL}[31,32]$. Repeatedly administering paliperidone ER produces stable, balanced concentrations on the fourth or fifth day, the $(+)$ enantiomer's $\mathrm{ABC}$ being 1.6 times greater than that of the (-) enantiomer [32]. Likewise, the index of fluctuation between maximum (peak) and minimum (trough) plasma concentrations after reaching equilibrium, is three times lower for paliperidone ER (38\%) than for oral risperidone (125\%). This finding, that paliperidone ER's level in the plasma fluctuates less, provides differential data to support the argument that it is more tolerable. In fact, paliperidone's gradual absorption means an initial dosage spike is not necessary in order to avoid orthostatic hypertension; in contrast, that is recommended in the case of risperidone [19].

Another interesting piece of data to take into account has to do with bioavailability. While paliperidone in solution (drug not commercialized) has almost total bioavailability, paliperidone ER's bioavailability is around $28 \%$. This difference is likely due to the fact that a considerable amount of osmotic paliperidone is released in the colon, where there is less absorption [19]. On that point, oral risperidone possesses an absolute bioavailability of $70 \%$, which to our understanding could begin to explain the dose ratio (2:1) employed by some clinicians in patients who have been previously treated with risperidone and are being switched to paliperidone ER [23].

On the other hand, taking paliperidone ER with food that is high in fat and calories, compared to taking it while fasting, increases $\mathrm{C}_{\max }$ and $\mathrm{ABC}$ to $50-60 \% ; \mathrm{T}_{\max }$ and elimination half-life $\left(\mathrm{T}_{1 / 2}\right)$ are hardly affected at all [33]. This seems to be due to ingestion slowing paliperidone ER's movement in the upper part of the digestive tract, thereby increasing absorption. For that reason, patients should always take paliperidone tablets under the same conditions (with or without food) to avoid fluctuations in plasma levels of the drug.

\section{Metabolism}

Metabolism of antipsychotic drugs in the liver is usually quite intense and complex, but in the case of risperidone, isoenzyme CYP2D6 is most critical $[34,35]$, because it converts the drug through hydroxylation into its primary active metabolite, 9-OH-risperidone, or paliperidone [36,37].

In contrast to the case of risperidone and other antipsychotics, paliperidone's metabolism in the liver is very limited; $60 \%$ of the molecule is eliminated, unaltered, in the urine (Figure 1). The rest is eliminated in the form of urinary metabolites through dealkylation (4.6\%), hydroxylation (3.8\%), dehydrogenation (2.7\%), and breakdown of the benzisoxazole nucleus (4.1\%), and a small amount in faeces. Even though in vitro studies have demonstrated that isoenzymes CYP2D6 and CYP3A4 can intervene in paliperidone metabolism, there are no in vivo data available to confirm whether or not said isoenzymes play a significant metabolic role. In a study of five healthy volunteers, after a single $1 \mathrm{mg}$ dose of immediate release paliperidone was taken orally, no metabolite was detected in the plasma [36,37].

Furthermore, in vitro studies of human, hepatic microsomes in subjects with genotypes UGT1A1 and UGT1A6 found that those enzymes do not influence paliperidone metabolism either [36,37].

Keep in mind that when other antipsychotic, substrates but not inhibitors of CYP450, are metabolized, their metabolism can be altered by inductors or inhibitors of isoenzymes, and pharmacokinetic interactions may occur. In the case of paliperidone, in vitro studies, conducted with human hepatic microsomes, confirmed the substance was neither a substrate nor a substantial metabolic inhibitor of medications metabolized by isoenzymes in cytochrome P450, like CYP1A2, CYP2A6, CYP2C8/9/10, CYP2D6, CYP2E1, CYP3A4, and CYP3A5 [36]. Therefore, that type of interaction is unlikely to occur.

This salient pharmacokinetic feature can be applied clinically in that paliperidone may benefit patients with liver failure, not only because it minimizes liver damage, but also because drug accumulation in the plasma is not possible for such patients [27].

Another noteworthy piece of differential data between risperidone and paliperidone lies in the presence of genetic polymorphism in the various isoforms in cytochrome P-450. CYP2D6 is subject to so-called "genetic polymorphism" considering that between 5 and $10 \%$ of racially white individuals are slow metabolizers [38]. Risperidone is a substrate of that isoenzyme, so higher levels of it will remain in the blood plasma of poorer metabolizers longer, while it will be present in lower levels and for less time in fast metabolizers.

Several clinical studies have shown that paliperidone is more stable in blood plasma than risperidone, due on the one hand to its special, extended absorption pharmaceutical mechanism, and on the other, to the fact that it is not affected by genetic changes in CYP450 [39]. On a similar note, studies by Vermeier et al. [36] have elucidated that none of paliperidone's metabolites surpass $5 \%$, with practically no difference between fast and slow metabolizers. These data seem to suggest that paliperidone's potential for metabolic interaction 
with agents metabolized by the aforementioned isoenzymes, then, is unlikely and not very applicable to clinical practice [40]. In addition, it seems unnecessary to make special instructions or recommendations for slow-metabolizing patients.

It seems unlikely that drug inductors or inhibitors in these enzymatic systems will alter paliperidone's pharmacokinetics [19]. In that vein, paroxetine's $(20 \mathrm{mg} /$ day $)$ influence has been examined; CYP2D6 was shown to strongly inhibit the release of paliperidone ER $(3 \mathrm{mg})$ in a total sample of 60 healthy volunteers, with no clinically significant differences observed in $\mathrm{ABC}$ or $\mathrm{C}_{\max }$ between groups treated with paliperidone alone, or paliperidone and paroxetine [41]. By the same token, no serious adverse effects or important clinical changes occurred in either group in terms of laboratory results, vital signs, or ECG, so beginning or ending concomitant treatment with pharmaceuticals inhibiting CYP2D6 would not seem to require any dose adjustment in paliperidone ER [41].

In contrast, several studies have reported that fluoxetine $[42,43]$ and paroxetine $[44,45]$ can both bring about an increase in risperidone levels, to the extent that it would be clinically relevant. Also, risperidone has a weak ability to inhibit CYP2D6 and serum levels of clozapine increase about $74 \%$ following a $2 \mathrm{mg}$ daily dose of risperidone [46].

Paliperidone's lack of metabolic drug interactions was definitively established by Tomlinson's [32] study, which included data collected from several clinical trials and a total sample of 616 schizophrenic patients being treated with paliperidone ER. The sample included slow metabolizers of CYP2D6. The study concluded there were no differences in the incidence of adverse effects between patients with the slow metabolizing phenotype and those with the normal phenotype.

In light of these data, it could be concluded that one of paliperidone's most important advantages over risperidone is its minimal hepatic biotransformation, which reduces the risk of clinically relevant drug interactions [27]. This is especially important considering that psychotic patients tend to present with comorbid pathologies requiring concomitant medications. It is therefore crucial that antipsychotics with little potential drug interaction be made available [47].

\section{Distribution}

A drug's distribution through an organism's different compartments depends on various factors, including the molecule's size, its solubility in lipids/water, and the extent of its plasma protein binding. In that vein, paliperidone's distribution is quick and extensive, as evidenced by its apparent $\mathrm{V}_{\mathrm{d}}$, which is on the order of $487 \mathrm{~L}$. Similarly, it gets well-distributed throughout the CNS according to the findings of displacement studies of 11C-raclopride that utilized positron emission tomography (PET) in a sample of healthy volunteers [31]. However, different quantities of risperidone and paliperidone do really manage to reach the central nervous system.

Plasma protein binding: Paliperidone, at therapeutic plasma concentrations between 50 and $250 \mathrm{ng} / \mathrm{mL}$, binds primarily to $\alpha_{1}$-acid glycoproteins and albumin at a rate of $74 \%$ (82\% for the $(+)$ enantiomer and $65 \%$ for the (-) enantiomer), and this binding seems to be uninfluenced by gender, age, or renal functioning [19]. This binding is lower than that of risperidone, which binds to $90 \%$ of plasma proteins [48]. Paliperidone's lower propensity to bind with plasma proteins even further reduces its possible interactions with other drugs. In fact, in vitro studies conducted with high concentrations of several substances that bind to plasma albumin (diazepam, warfarina, carbamazepina) only produced a slight increase in available paliperidone [31], leading us to believe that pharmacological interactions via protein displacement are unlikely with paliperidone, and certainly less likely than with risperidone.

Since paliperidone can bind to $\alpha_{1}$-acid glycoprotein, a special precaution must be taken for patients suffering from moderate to severe liver failure who therefore synthesize fewer of such proteins, as with all drugs that bind to $\alpha_{1}$-acid glycoprotein and albumin. Nevertheless, Boom et al. [49] confirmed that the pharmacokinetic profile of nonplasma protein-bound paliperidone was similar between patients with moderate liver failure and control subjects, so it is not necessary to adjust the dose in those patients.

Structural differences influence paliperidone's distribution in the brain: Placing a hydroxyl group in position 9 of the risperidone molecule, a seemingly small chemical change, creates structural differences between the two products that affect its passage through the $\mathrm{BBB}$. Accordingly, the Brain/Blood ratio $(\log \mathrm{B} / \mathrm{B})$ of paliperidone $(\log \mathrm{B} / \mathrm{B}=-0.67)$ is five times less than risperidone's $(\log \mathrm{B} / \mathrm{B}=-0.02)$ $[50,51]$. Paliperidone has less cerebral distribution for various reasons. First, there is a known, high correlation between a compound's dynamic polar molecular surface area and its ability to permeate cellular membranes, particularly the blood-brain barrier (BBB), through passive diffusion. The presence of an $\mathrm{OH}$ group at position 9 in paliperidone's molecular structure lends it greater dynamic surface area $\left(74.28 \mathrm{~A}^{2}\right)$ than risperidone has $\left(57.32 \mathrm{~A}^{2}\right)$. This makes the correlation between cerebral and plasma drug concentrations higher for risperidone. While both drugs can enter the CNS through passive diffusion, because paliperidone's dynamic polar surface area falls below the threshold of $120 \mathrm{~A}^{2}$ [52], it does so more slowly, or less so, than risperidone.

Katritzky et al. [53] recently developed computerized models (CODESSA-PRO and ISIDA) to calculate blood/brain barrier coefficients $(\log \mathrm{BB})$, a measure of a drug's penetration of the $\mathrm{BBB}$, estimating values between -0.18 and -0.24 for risperidone and between -0.98 and -0.70 for $9-\mathrm{OH}$-risperidone, respectively. These data indicate that risperidone and paliperidone both cross the $\mathrm{BBB}$, but risperidone does so to a greater extent. This pharmacokinetic data may explain some of the existing differences in the two drugs' clinical profiles, and in the dosages of each substance recommended in clinical practice.

P-glycoprotein and differential cerebral distribution of paliperidone vs. risperidone: P-glycoprotein, or Pgp (Permeabilityglycoprotein) is a protein in the glycated, phosphorylated plasma membrane, one of large dimensions $(170 \mathrm{kDa})$ that is broadly distributed throughout the organism. It acts as a detoxifying and defense mechanism against what are referred to as anatomical "sanctuary sites" $[54,55]$, eliminating or pumping toxic agents and xenobiotics, including drugs, from the inside of the cell by means of an ATP-dependent pump mechanism [56,57]. Pgp inhibition increases systemic exposure and tissue distribution of Pgp substrates, while its induction has the opposite effects [58-60].

According to studies conducted in vitro, among antipsychotics, risperidone and quetiapine are considered good substrates and therefore potential Pgp inhibitors. Both olanzapine and chlorpromazine are intermediate substrates, while clozapine and haloperidol are considered poor substrates [61].

Paliperidone $(149.6 \pm 29.7 \mathrm{mM})$ has much lower affinity than risperidone $(26.3 \pm 5.5 \mathrm{mM})$ for Pgp [62,63]. Zhu et al. [64] looked at cellular overexpression of Pgp (LLC-PK1/MDR1), finding that risperidone was between 3.8 and 2.2 times more inhibitory of Pgp than 
paliperidone at the same concentration (Figure 3). Likewise, studies of knockout (KO) mice lacking Pgp reported a brain/blood ratio 14 times higher in $\mathrm{KO}$ mice than control mice for risperidone, and 11 times higher for 9-OH-risperidone; these differences were statistically significant [62]. In addition, they discovered significant differences between $\mathrm{KO}$ and control mice in brain/blood and brain/brain ratios for paliperidone [55-61]. Altogether, these data suggest that paliperidone, at least at therapeutic concentrations, cannot be considered a $\operatorname{PgP}$ inhibitor, differentiating it from risperidone [51-65]. Therefore, its presence in the CNS is limited by its expulsion through the PgP efflux pump. What is more, it seems unlikely that paliperidone interferes to a clinically relevant extent with the functioning of P-glycoprotein, whether encouraging its accumulation or that of other drugs at the cerebral level [66].

In light of the above, though no studies have been conducted in humans, mounting evidence collected in animals and through in vitro studies supports the notion that paliperidone has more difficulty penetrating the CNS than risperidone. This may explain risperidone's higher potency and toxicity compared to paliperidone. Furthermore, higher plasma concentrations of paliperidone are needed to reach levels in the brain similar to those of risperidone [23].

\section{Elimination}

As discussed above, paliperidone may be considered to have a low index of hepatic extraction in that its plasma clearance $(80 \mathrm{ml} /$ $\mathrm{min})$ is somewhat lower than its hepatic plasma flow $(700 \mathrm{ml} / \mathrm{min})$. Paliperidone's elimination half-life $\left(\mathrm{T}_{1 / 2}\right)$ is 20-25 hours regardless of dose, how it is administered, and pharmaceutical formulation. Generally speaking, paliperidone is excreted mostly in the urine (80\%) unaltered (60\%), while a small amount is excreted as feces (11\%). As for renal clearance, the clearance of unaltered paliperidone is $53 \mathrm{ml} /$ min; $50 \%$ of that is through glomerular filtration $\left(\mathrm{CL}_{\mathrm{GFR}}: 25.9 \mathrm{ml} / \mathrm{min}\right)$ and the other $50 \%$ through active mechanisms $\left(\mathrm{CL}_{\mathrm{ACT}}: 27.2 \mathrm{ml} / \mathrm{min}\right)$ $[19,31]$.

Tubular secretion through active transport seems to play a critical role in eliminating 9-OH-risperidone, probably via organic cation transport. Nevertheless, administering trimethoprim, a strong inhibitor of organic cation transport, does not significantly affect paliperidone ER's pharmacokinetic parameters [67].

Bear in mind that paliperidone clearance is proportional to renal functioning, such that in patients with severe renal failure, it is $71 \%$ lower than in control subjects. Similarly, in patients with slight renal failure (renal clearance of creatinine between 50 and $80 \mathrm{ml} / \mathrm{min}$ ), doses of paliperidone ER should not exceed $6 \mathrm{mg} /$ day. In patients with moderate-severe renal failure (creatinine clearance between 10 and 50 $\mathrm{ml} / \mathrm{min}$ ), the maximum dose falls to $3 \mathrm{mg} /$ day $[19,31]$.

Half life $\left(T_{1 / 2}\right)$ : One of the main differences between risperidone and paliperidone ER lies in their respective half lives $\left(\mathrm{T}_{1 / 2}\right): 2.8 \mathrm{~h}$ and 24.8 hours (Table 1 ). $\mathrm{T}_{1 / 2}$ provides clinically applicable information by indicating the time the drug needs to be eliminated after treatment is discontinued, the number of doses per day, and fluctuation in plasma levels over the course of the day. $\mathrm{T}_{1 / 2}$ addresses the possible link between the drug's permanence in the organism and its beneficial or harmful effects. In addition, $T_{1 / 2}$ is a useful tool to evaluate the time needed for the drug to reach a steady state, and a valuable measure of its longevity in the organism. After administering medication, an estimated five half lives are needed to eliminate $96 \%$ of it, and almost six half lives to eliminate $98 \%$ [23].
With this in mind, and given risperidone's short half-life (2.8 $\mathrm{h}$ ), taking it twice a day would result in lower peaks, making it more tolerable than a once daily dose. Conversely, paliperidone ER's long half-life $(24.8 \mathrm{~h})$ allows for one daily dose for lower peaks, fewer fluctuations, and improved tolerability [23].

\section{Pharmacodynamic Differences: Paliperidone Er Vs. Risperidone}

Differences between paliperidone and risperidone are not limited to pharmacokinetic aspects; certain pharmacodynamic distinctions may have a clinical impact. Below, we will discuss the differential properties of paliperidone and risperidone within the framework of the hypothesized mechanism for atypical antipsychotics' activity, and sources of adverse effects tied to receptor profile.

\section{Differential profile of paliperidone vs. risperidone and} dopamine $\mathrm{D}_{2}$ receptors

In 1976, Solomon H. Snyder reported that neuroleptics were dopamine $\mathrm{D}_{2}$ receptor antagonists and that their effects were proportional to clinical potency and to extrapyramidal and endocrine effects [68]. Later, through neuroimaging studies (PET, SPECT) in humans, an antipsychotic effect was linked to blocking more than $65 \%$ of $\mathrm{D}_{2}$ receptors. It was also established that occupancy levels over $72 \%$ of $\mathrm{D}_{2}$ receptors located in the tuberoinfundibular pathway were responsible for prolactin elevation. Meanwhile, occupancy of over $80 \%$ of striatal $\mathrm{D}_{2}$ receptors yielded adverse extrapyramidal effects [69]. Hence, we must maintain the therapeutic window between $65 \%$ and $80 \%$ to yield therapeutic effects with no extrapyramidal side effects.

Precisely paliperidone differs from risperidone, among other things, on its ability to block dopamine $\mathrm{D}_{2}$ receptors. Along those lines, several experimental studies have shown paliperidone to occupy fewer of said receptors. Receptor occupancy (affinity), determined by $\mathrm{ED}_{50}$ values (effective dose to occupy $50 \%$ of receptors) (nM) of dopamine $\mathrm{D}_{2}$ receptors in "ex vivo" rat brains: $2.92 \mathrm{nM}$ for risperidone and much higher, $8.68 \mathrm{nM}$, for paliperidone [70]. These data convey that paliperidone's $\mathrm{D}_{2}$ receptor affinity is approximately 3 times lower than risperidone's (Figure 4).

By the same token, receptor binding studies have determined the dissociation constant $\left(\mathrm{K}_{\mathrm{d}}\right)$ in the caudate nucleus of human brains

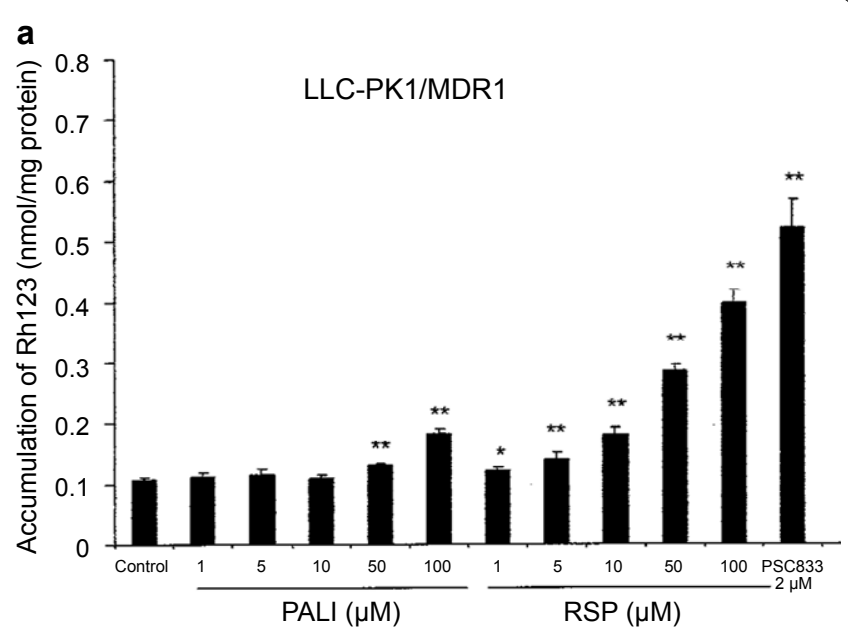

Figure 3: Capacity of Pgp inhibition by paliperidone vs. risperidone. Modified from Zhu et al. [64]. 


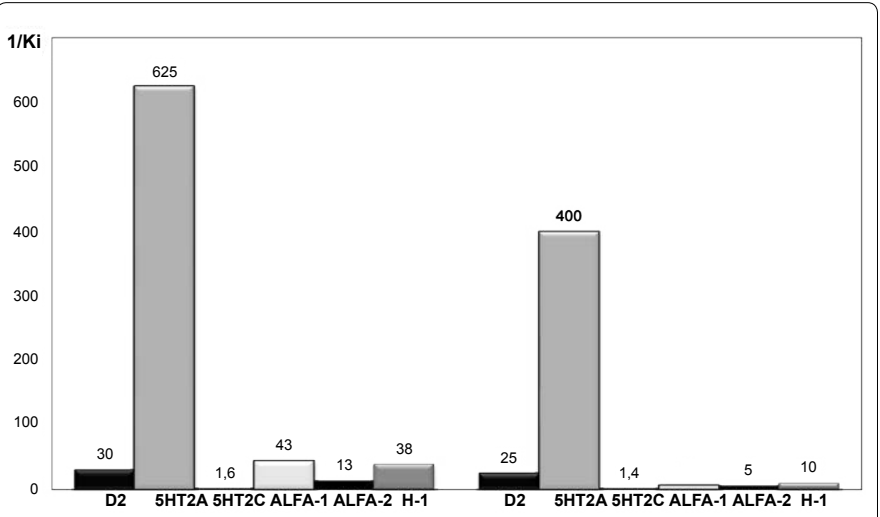

Figure 4: Receptor profile of risperidone vs. paliperidone ("in vitro" data) (nM 1/ $\mathrm{Kd}$ x 100). Modified from Schotte et al. [71].

"post mortem," confirming risperidone's higher affinity $\left(\mathrm{K}_{\mathrm{d}}=3.77 \mathrm{nM}\right)$ for these receptors than paliperidone's $\left(\mathrm{K}_{\mathrm{d}}=2.8 \mathrm{nM}\right)$ [72].

Furthermore, neuroimaging studies of schizophrenic patients reported that paliperidone ER's occupancy of striatal and temporal lobe receptors had $\mathrm{ED}_{50}$ values of 2.38 and $2.84 \mathrm{mg} /$ day, respectively [50]. Earlier studies of risperidone found a striatal $\mathrm{ED}_{50}$ value of $1.2 \mathrm{mg} /$ day [73] and a limbic lobe $\mathrm{ED}_{50}$ value of $1.46 \mathrm{mg} /$ day [74]. These studies' findings suggest a 1:2 ratio between risperidone and paliperidone ER doses would be apt.

In this study, paliperidone ER at a dose of 6 to $9 \mathrm{mg} / \mathrm{day}$ yielded occupancy of 70 to $80 \%$ of striatal and temporal lobe dopamine $\mathrm{D}_{2}$ receptors. Paliperidone ER's estimated occupancy of $\mathrm{D}_{2}$ receptors at a dose of $6 \mathrm{mg} /$ day was around $72 \%$. This dose could be considered suitable, because it maintains $\mathrm{D}_{2}$ receptor occupancy levels above the threshold of effectiveness, yet below the threshold of extrapyramidal side effects [50]. By the same token, it is accepted that antipsychotic efficacy be linked to $\mathrm{D}_{2}$ receptor occupancy in the basal ganglion over $65 \%$, but when occupancy exceeds $80-85 \%$, extrapyramidal side effects increase [29]. Given paliperidone ER's lower occupancy of $\mathrm{D}_{2}$ receptors, and that its plasma levels fluctuate less [75], it should in theory have less extrapyramidal effects than risperidone [76].

In addition, quantitative autoradiographic studies show that $\mathrm{ED}_{50}$ two hours after administering the antipsychotic is lower for risperidone than paliperidone in several areas of the brain: the nucleus accumbens $\left(\mathrm{ED}_{50}: 0.75\right.$ vs. 2$)$, olfactory tubercle $\left(\mathrm{ED}_{50}: 0.96\right.$ vs. 4.1$)$, striatum $\left(\mathrm{ED}_{50}\right.$ : 1.2 vs. 3.7$)$, and the pars compacta within the substancia nigra $\left(\mathrm{ED}_{50}: 1\right.$ vs. 3.3). These data hold that risperidone has a greater capacity for $\mathrm{D}_{2}$ receptor occupancy than paliperidone, and therefore more intensely blocks said receptors. This is an important consideration; to yield an antipsychotic effect equivalent to that of risperidone, one would need a higher dose of paliperidone [71].

In effect, there seems to be a certain correlation between plasma levels of antipsychotics and the incidence of extrapyramidal symptoms. In the case of risperidone, the dosage threshold for parkisonism is around $6 \mathrm{mg} /$ day [77], somewhat lower than that of paliperidone ER.

However, dose is not the sole influence in the genesis of extrapyramidal side effects; fluctuations in antipsychotics' plasma levels also seem to be of considerable import. For example, Yoshimura et al. [78] established in schizophrenic patients that a $4 \mathrm{mg} /$ day dose of risperidone produced extrapyramidal side effects only in patients who exhibited plasmatic fluctuations of the antipsychotic and its metabolite. Nevertheless, with longer-lasting risperidone injections, fewer extrapyramidal side effects occurred. That may be due to the fact that the injectable drug's $\mathrm{C}_{\max }$ (maximum concentration) in plasma was $30 \%$ lower than in tablet form. The tablets are associated with fewer plasmatic fluctuations [79].

There are fewer fluctuations in plasma levels of paliperidone ER, which is considered one of the osmotic drug form's best attributes. In a study conducted in a sample of 4 healthy volunteers administered a single, $6 \mathrm{mg}$ dose of paliperidone ER, average dopamine $\mathrm{D}_{2}$ receptor occupancy was $64 \%$ after 22 hours and $53 \%$ after 56 hours [80]. A different study by the same research group examined paliperidone ER's striatal $\mathrm{D}_{2}$ receptor occupancy compared to an immediate release pharmaceutical form (drug not commercialized), reporting minimal fluctuation in $\mathrm{D}_{2}$ receptor occupancy $(75-78 \%), 6$ times lower than what was obtained with immediate release paliperidone (64-83\%) $[26,81]$. This slight fluctuation in paliperidone ER at nigrostriatal $\mathrm{D}_{2}$ receptors translates to a favorable profile in terms of extrapyramidal side effects; this was confirmed in clinical trials of this antipsychotic [82].

According to an analysis of data collected from several clinical studies, rates of extrapyramidal effects associated with paliperidone ER doses of 3 and $6 \mathrm{mg} /$ day were similar to those observed with a placebo [83]. However, at higher doses ( 9 and $12 \mathrm{mg} /$ day), extrapyramidal effects increased, surpassing what was observed in the placebo condition. These effects were categorized as slight or moderate and only two patients discontinued treatment because of said effects [84]. A yearlong study reported that no patients worsened due to extrapyramidal side effects, and a drop-out rate of less than $1 \%$ [85]. The incidence of extrapyramidal side effects in elderly individuals treated with paliperidone is generally low, with hypertonia, tremor, and akathisia occurring in only two of the study's 76 patients (3\%). In patients taking the placebo, akathisia was reported in one case. During the 6-month span, none of the elderly individuals treated with paliperidone ER discontinued treatment due to secondary, extrapyramidal issues [86].

On the other hand, risperidone and paliperidone are known to heighten prolactin secretion. Risperidone causes dose-dependent hyperprolactinemia [87,88], which some studies have shown [89-90], correlates directly with its metabolite, 9-OH-risperidone. In a 6-day study comparing the two substances, paliperidone ER at a dose of 12 $\mathrm{mg} /$ day was found to produce an increase in serum concentrations of prolactin similar to what risperidone would produce at $4 \mathrm{mg} /$ day [91]. Paliperidone ER, at 3 daily doses of $12 \mathrm{mg} /$ day, had an incidence of adverse effects related to prolactin elevation (1-2\%) similar to what was observed in the placebo condition, but that rate went up (4\%) when the dose of paliperidone ER rose to $15 \mathrm{mg} /$ day [85]. Keep in mind that the dopamine receptors that control prolactinemia are not protected by the $\mathrm{BBB}$, so plasma levels of the antipsychotics are responsible for higher or lower prolactin release [92]. In that sense, we know paliperidone crosses the $\mathrm{BBB}$ less than risperidone, which could explain the risperidone metabolite's involvement in prolactin release.

\section{Speed of dissociation from the dopamine $D_{2}$ receptor for paliperidone vs. risperidone}

Another way to explain how an antipsychotic could improve extrapyramidal tolerability is the speed with which it dissociates from the $\mathrm{D}_{2}$ receptors $[93,94]$. It is been demonstrated that some atypical agents have the ability to dissociate quickly from the receptor, while classical drugs do so more slowly.

By way of example, note that the speed of dissociation from dopamine $\mathrm{D}_{2}$ receptors in humans is slow for haloperidol, 
chlorpromazine, and raclopride (around thirty minutes). Some atypical antipsychotics exhibit an intermediate speed of dissociation from the $\mathrm{D}_{2}$ receptor, including olanzapine, asenapine, sertindole, ziprasidone, and risperidone. However, other atypical antipsychotics dissociate quickly, like clozapine, quetiapine, amisulpride, remoxipride, and paliperidone, in nearly 1 minute [76]. In terms of dissociation speed, paliperidone fits the latter profile (Figure 5).

Kapur and Seeman $[93,94]$ suggest that fast dissociation from dopamine $\mathrm{D}_{2}$ receptors, in addition to producing an antipsychotic effect as a dopamine antagonist, better accommodates physiological dopamine transmission, so fewer of the extrapyramidal effects associated with nigrostriatal modulation occur. Furthermore, by enhancing the functioning of endogenous dopamine binding, these antipsychotics bear cognitive and emotional benefits and improve negative symptoms displays data on dissociation from dopamine $\mathrm{D}_{2}$ receptors for a series of antipsychotics studied in vitro. It is noteworthy that paliperidone's dissociation time from human cloned $\mathrm{D}_{2}$ receptors is noticeably lower ( 1 minute) than risperidone's (27 minutes) [76]. Clearly, the theory of fast dissociation from the receptor (fast-off) is not valid for every antipsychotic that behaves atypically, yet it does draw a distinction between the behavior of risperidone (slow-off) and its active metabolite, paliperidone (fast-off).

Thus, a paradigm shift has occurred from considering extrapyramidal effects to be an outcome of the proportion of receptors blocked (usually over 80\%), to an outcome of the antipsychotic's speed of dissociation from the receptor, such that more adverse effects occur the longer the antipsychotic takes to leave a given $\mathrm{D}_{2}$ receptor [95]. This hypothesis would explain paliperidone's low risk of extrapyramidal effects considering, its fast dissociation.

On the other hand, the incidence of extrapyramidal effects reported in risperidone use, especially at high doses, may be due to its high capacity for $\mathrm{D}_{2}$ blockade, coupled with slow dissociation speed. Ergo, its atypicality can be explained by other mechanisms. First of all, its higher capacity for 5- $\mathrm{HT}_{2 \mathrm{~A}}$ blockade speaks to the drug's atypicality. Yet it is also crucial to consider that risperidone is converted into its active metabolite, 9-OH-risperidone, which quickly dissociates from dopamine $\mathrm{D}_{2}$ receptors, so the higher the rate of conversion into its metabolite, the fewer extrapyramidal effects it will have.

\section{Serotonin $5-\mathrm{HT}_{2 \mathrm{~A}}$ receptor occupancy $>\mathrm{D}_{2}$ as hypothesis for atypicality}

Presently, the most plausible hypothesis for the "atypicality" of antipsychotics posits "dopamine-serotonin antagonism" and was conceived of by Janssen et al. [96] and popularized by Meltzer et al. [97]. According to this theory, greater ability to block 5- $\mathrm{HT}_{2 \mathrm{~A}}$ than $\mathrm{D}_{2}$ receptors $\left(5-\mathrm{HT}_{2 \mathrm{~A}}>\mathrm{D}_{2}\right)$ confers atypicality to an antipsychotic. Along those lines, $5-\mathrm{HT}_{2 \mathrm{~A}}$ antagonism can increase dopaminergic transmission in the nigrostriatal pathway, reducing the risk of extrapyramidal effects. Furthermore, this relationship of $5 \mathrm{HT}_{2 \mathrm{~A}}>\mathrm{D}_{2}$ blockade in the prefrontal cortex would improve negative, cognitive symptoms of schizophrenia by increasing dopamine and acetylcholine release [98]. However, $5-\mathrm{HT}_{2 \mathrm{~A}}$ blockade does not affect the mesolimbic pathway, so it would not increase dopamine release in that area, leaving the atypical agent's antipsychotic properties unhindered [99]. Most antipsychotics' atypicality, asenapine, clozapine, iloperidone, olanzapine, paliperidone, quetiapine, risperidone, sertindole, ziprasidone, and zotepine, for example, could be explained by this hypothesis since they all blockade $5-\mathrm{HT}_{2 \mathrm{~A}}$ and $\mathrm{D}_{2}$ receptors such that5- $\mathrm{HT}_{2 \mathrm{~A}}>\mathrm{D}_{2}[100,101]$.

In that vein, the hypothesis above does not contradict that of
Kapur and Seeman [93,94] about speed of dissociation from $\mathrm{D}_{2}$ receptors; rather, they complement one another. Increased dopamine release, a secondary effect of 5- $\mathrm{HT}_{2 \mathrm{~A}}$ facilitates antipsychotics' speed of dissociation from its receptors [16].

Notwithstanding that contribution, this hypothesis is not without limitations. For example, the atypical antipsychotic amisulpride has low affinity for $5-\mathrm{HT}_{2 \mathrm{~A}}$ receptors. Aripiprazole has greater $\mathrm{D}_{2}$ affinity than $5-\mathrm{HT}_{2 \mathrm{~A}}$ affinity despite being an atypical antipsychotic. Also, two classical antipsychotics, chlorpromazine and loxapine, have greater affinity for $5-\mathrm{HT}_{2 \mathrm{~A}}$ than $\mathrm{D}_{2}$, yet they do not meet the atypical profile. Additionally, risperidone and olanzapine, which exhibit 5- $\mathrm{HT}_{2 \mathrm{~A}}>\mathrm{D}_{2}$ receptor occupancy, can cause extrapyramidal effects at high doses despite very elevated $5-\mathrm{HT}_{2 \mathrm{~A}}$ occupancy. Therefore, higher $5-\mathrm{HT}_{2 \mathrm{~A}}>\mathrm{D}_{2}$ affinity may promote dopamine release in the striatum and prefrontal cortex, but it does not protect against extrapyramidal symptoms if $\mathrm{D}_{2}$ receptor occupancy passes a certain threshold [101,102]. Therefore, these receptors' participation in atypical antipsychotic activity seems to be more a result of dominance in dopamine $\mathrm{D}_{2}$ blockade than of isolated $5-\mathrm{HT}_{2 \mathrm{~A}}$ antagonist ability. Moreover, higher doses of atypical agents could make that dominance disappear [95]. Despite these limitations, the hypothesis that best captures atypicality is the one that postulates greater $5-\mathrm{HT}_{2 \mathrm{~A}}$ blockade than $\mathrm{D}_{2}$ blockade $[95,103]$.

With the above in mind, utilizing neuroimaging techniques in schizophrenic patients being treated long-term with antipsychotics, it has been observed that risperidone's occupancy is approximately $80 \%$ for dopamine $\mathrm{D}_{2}$ receptors in the striate nucleus, and between 86 and $93 \%$ for serotonin $5-\mathrm{HT}_{2 \mathrm{~A}}$ receptors in the cerebral cortex. Other authors reported similar data about clozapine, olanzapine, quetiapine, and ziprasidone [104-108]. In contrast, administering classical neuroleptics blocks between 70 and $90 \%$ of striatal $\mathrm{D}_{2}$ receptors and does not significantly occupy serotonin $5-\mathrm{HT}_{2 \mathrm{~A}}$ receptors $[100,109]$.

Paliperidone's binding to $5-\mathrm{HT}_{2 \mathrm{~A}}$ receptors is $0.25 \mathrm{nM}$, compared to risperidone's $0.16 \mathrm{nM}$ [76]. Data collected in rats by Schotte et al. [70] are on the order of $0.15 \mathrm{nM}$ for risperidone and $0.82 \mathrm{nM}$ for paliperidone. In both cases, paliperidone's affinity for $5-\mathrm{HT}_{2 \mathrm{~A}}$ receptors

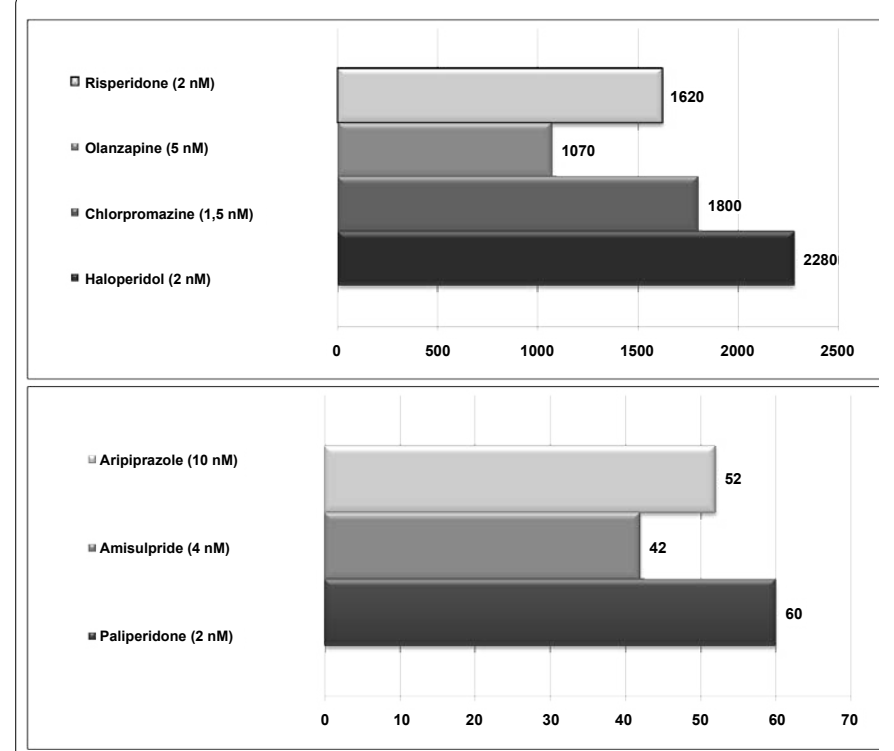

Figure 5: Time of antipsychotic drug dissociation from the $\mathrm{D}_{2}$ receptor $(50 \%)$ Modified from Seeman [76]. 
is lower than risperidone's. However, paliperidone's ability to block $5-\mathrm{HT}_{2 \mathrm{~A}}$ receptors is almost 20 times higher than its blockade of $\mathrm{D}_{2}$ receptors, fitting the hypothesis that antipsychotics' atypicality lies in their serotonin vs. dopamine antagonism.

The fact that paliperidone ER exhibits receptor occupancy such that $5-\mathrm{HT}_{2 \mathrm{~A}}>\mathrm{D}_{2}$ with little plasma fluctuation, the ability to gradually occupy $\mathrm{D}_{2}$ receptors, and quick dissociation from said receptors, are all grounds to consider it an atypical antipsychotic with a lower risk of extrapyramidal side effects than risperidone has $[76,110]$.

\section{Occupancy of other receptors by paliperidone and risperidone}

In general, antipsychotics are not very selective from the perspective of receptors, so their activity at non-target receptors ought to be considered, since that can alter overall neural performance and is responsible for certain therapeutic peculiarities and above all, adverse effects. Many of these agents simultaneously interact with different types of receptors (dopaminergic, serotonergic, histaminergic, $a$-adrenergic, muscarinic), which has an impact on the overall response of neurons and functional systems involved in their effectiveness and tolerability [111]. Though not all functions of each receptor are exactly known, understanding each antipsychotic's receptor profile, heeding its efficacy and any secondary effects is useful in guiding patients toward choosing an appropriate medical regimen [112].

$5-\mathrm{HT}_{2 \mathrm{C}}$ receptor blockade seems to be closely linked to antipsychotic-induced weight gain, but it is not solely responsible for weight gain $[113,114]$. Neither risperidone nor paliperidone is believed to show significant affinity for said receptor.

Some antipsychotics can boost appetite and weight by jointly blocking receptors 5- $\mathrm{HT}_{2 \mathrm{C}}$ and $\mathrm{H}_{1}$ [115]. $\mathrm{H}_{1}$ and 5- $\mathrm{HT}_{2 \mathrm{C}}$-antagonist antipsychotics include clozapine, olanzapine, and quetiapine, and correlate with weight increase in patients.

Despite the fact that risperidone has lower $\mathrm{H}_{1}$ receptor affinity, weight gain is also associated with the atypical agent, especially in children and adolescents [116]. Paliperidone has less affinity for receptors $5-\mathrm{HT}_{2 \mathrm{C}}$ and $\mathrm{H}_{1}$ than risperidone, so weight gain should be more moderate. An analysis of the data collected in three controlled studies elucidated that paliperidone ER was no different from the placebo after 6 weeks of treatment, in terms of weight, lipid parameters, or blood sugar [117]. Nevertheless, an additional increase of 1.2 kilograms was observed in patients who continued treatment with paliperidone ER in three randomized studies conducted over the course of 52 weeks [118].

Certain antipsychotics' ability to block adrenergic $\alpha_{1}$ receptors seems to explain their potential to bring about cardiovascular or orthostatic effects, erectile dysfunction (impotence), akinesia, and sedation. Risperidone is one such drug $\left(\mathrm{K}_{\mathrm{d}}=2.7 \pm 0.3 \mathrm{nM}\right)$. Paliperidone's affinity for these receptors is almost 4 times lower than risperidone's. However, there are data that point to possible orthostasis, but that risk is lower than in the case of risperidone [118].

Likewise, certain atypical antipsychotics can also block $\alpha_{2}$ adrenergic receptors. Risperidone is among the drugs most capable of blocking these receptors $\left(\mathrm{K}_{\mathrm{d}}=8 \pm 1 \mathrm{nM}\right) . \alpha_{2}$-adrenergic receptors in the prefrontal cortex promotes dopamine release and can contribute to the cognitive improvement that antipsychotics bring about $[95,100]$. Paliperidone has less affinity for said adrenergic receptors $\left(K_{d}=80 \pm 10\right.$ $\mathrm{nM}$ ) than risperidone [72].

Paliperidone has a low affinity for muscarinic receptors, producing scarcely any central or peripheral anticholinergic effects [119]. What is more, said lack of anticholinergic effects may be beneficial in terms of certain psychotic symptoms, like visual hallucinations, disorientation, and agitation, and in the cognitive sphere (learning and memory), but these hypotheses must be compared through apt, specific clinical trials [27]. Paliperidone has low $\beta$-adrenergic receptor affinity [72].

\section{The differential electrophysiological profile of paliperidone vs. risperidone}

A neuron's electrophysiological behavior is a manifestation of pharmacological activity at its different receptors. Along those lines, risperidone is known, independently of dose, to inhibit neuronal release of serotonin, while paliperidone is unable to modulate that release. Recovery of serotonin release inhibited by risperidone can be achieved by jointly administering a $5-\mathrm{HT}_{1 \mathrm{~A}}$ (WAY 100635) receptor blockade and a norepinephrine reuptake inhibitor (desipramine). Hence, we can conclude that risperidone inhibits the release of 5-HT neurons by activating autoreceptors $5-\mathrm{HT}_{1 \mathrm{~A}}$ and blocking $\alpha_{1}$ receptors, leading us to believe paliperidone is less active at these two receptors than risperidone [110].

Although paliperidone does not alter norepinephrine release per se, it can revert escitalopram-induced suppression of norepinephrine release without changing the SSRI's role in serotonin release. This can be a useful adjuvant treatment in refractory depression. Similarly, paliperidone can be considered different from other atypical antipsychotics. It does not inhibit neuronal release of serotonin like olanzapine and clozapine by inhibiting $\alpha_{1}$ receptors, and unlike ziprasidone and aripiprazole, it is not a $5-\mathrm{HT}_{1 \mathrm{~A}}$ receptor agonist [110]. The differences between paliperidone and risperidone, as far as norepinephrine release in vivo, may be due to its low capacity to bind at $5-\mathrm{HT}_{2 \mathrm{~A}}$ and $\alpha_{1}$-receptors, observed in vitro [71].

\section{Differential profile of paliperidone: neurotoxicity and neuroprotection}

Recent studies' findings suggest that some atypical antipsychotics may have a neuroprotective impact that could be involved in cognitive improvement, or at least preventing the progression of an illness and its associated impairment, though these effects have not been reported consistently [120]. On another note, antipsychotics' neurotoxic effects have been linked to secondary effects, particularly extrapyramidal side effects and tardive dyskinesia. It is been demonstrated in vitro that classical antipsychotics, including haloperidol, reduce neuronal cells' viability [121], causing apoptosis, necrosis, and increasing oxidative stress $[122,123]$. Furthermore, in vitro studies have shown that while haloperidol is apparently neurotoxic, some atypical antipsychotics have shown antiapoptotic properties [124].

On another note, it has been shown that haloperidol, through intracellular accumulation of peroxides followed by depletion of intracellular glutathione, can cause oxidative stress in hippocampal cells [125]. Classical antipsychotics, clozapine, quetiapine, and risperidone can protect $\mathrm{PC} 12$ cells by regulating the expression of copper/zincdependent superoxide dismutases (SOD1) [126].

In an ex vivo study, paliperidone induced expression of proteins in the prefrontal cortex similar to that of lithium and valproic acid. These changes could affect oxidative phosphorylation, electron transport, metabolism of carbohydrates, and postsynaptic signal transduction. According to these results, like lithium and valproic acid, paliperidone is involved in neuronal signaling pathways, energetic metabolism, 
and synaptic plasticity, so it is postulated to have a mood stabilizing mechanism like that of lithium and valproic acid [127].

Haloperidol and the atypical antipsychotic clozapine have been reported to have toxic effects in both neuroblastoma cell lines (SHSY5Y) and monocytes (U937). Both cell lines are considered to be involved in the pathogenesis of schizophrenia. In this model, low concentrations of risperidone $(1.6-12.5 \mu \mathrm{g} / \mathrm{mL})$ increase cell survival, while paliperidone significantly improves survival of SH-SY5Y cells and U-937 cells at a concentration of $1.6 \mu \mathrm{g} / \mathrm{mL}$ [128].

A study of SH-SY5Y cells was conducted, applying various aggressive substances (MPP+, A $\beta 25-35$ and hydrogen peroxide) during treatment with antipsychotics: haloperidol, olanzapine, risperidone, and paliperidone. After 24 hours of treatment, paliperidone had the lowest basal toxicity over other antipsychotics. Furthermore, the group treated with paliperidone showed significantly higher cell survival than the cultures treated with other antipsychotics. At low concentrations $(10$ and $50 \mu \mathrm{M})$, paliperidone showed itself to be effective against $A \beta 25$ 35 and MPP+. In addition, paliperidone was the only antipsychotic that could protect $\mathrm{SH}-\mathrm{SY} 5 \mathrm{Y}$ cells against hydrogen peroxide.

It $(100 \mu \mathrm{M})$ completely diminished cell death caused by the aggressive substances mentioned above, regardless of their concentration. Compared to other antipsychotics, paliperidone proved better able to control oxidative stress by generating glutathione, decreasing HNE (4-hydroxy-2-nonenal), and producing carbonyl. Olanzapine, on the other hand, under similar conditions, increased HNE and carbonyl production, which might explain its cytotoxicity [33].

A recent study conducted on cultures of human neuroblastoma cells compared the effects of haloperidol, risperidone, and paliperidone $(10,50,100 \mu \mathrm{M})$, both alone and accompanied by dopamine, on the cells' viability and caspasa- 3 activity. Haloperidol, both alone and accompanied by dopamine, significantly decreased cellular viability while increasing caspase-3 activity and cell death. In contrast, neither risperidone nor paliperidone had an impact on cellular viability or cell death. Both atypical antipsychotics' caspase-3 activity declined, especially paliperidone's. In cells treated with dopamine as well as an antipsychotic, only paliperidone $(10 \mu \mathrm{M})$ brought about slight improvement in cellular viability. While haloperidol sparked a dopamine-induced increase in caspase- 3 activity, risperidone and paliperidone showed less of such an effect. These results reveal that haloperidol causes apoptosis, while risperidone and paliperidone can protect against apoptosis. Along those lines, paliperidone consistently showed itself to be strongest neuroprotector of the group [124].

These data together suggest that paliperidone, from the point of view of neurotoxicology and neuroprotection, behaves differently from classical and other atypical antipsychotic drugs, also setting itself apart from risperidone.

\section{Conclusions}

Paliperidone, as active metabolite of risperidone, is quantitatively different from risperidone from the perspective of pharmacodynamics as well as pharmacokinetics.

Experimental and clinical studies indicated that paliperidone ER differs from other classical and atypical antipsychotics, even from risperidone. Paliperidone ER's theoretical advantages in terms of efficacy and tolerability, compared to risperidone and possibly other second-generation antipsychotics, are linked to its formulation, pharmacokinetics, and to a lesser extent, its pharmacodynamic profile.
Paliperidone ER's osmotic formulation (OROS technology) provides constant release of the primary agent for 24 hours and reduces fluctuations in plasma levels of the drug. This formulation allows for a single daily dose to be taken, which is easier to accomplish and does not require initial dose titration. On the other hand, paliperidone's gradual, continuous release facilitates stable occupancy of $\mathrm{D}_{2}$ receptors, which can provide constant therapeutic effectiveness with fewer peaks and troughs, as well as a lower incidence of side effects. Paliperidone is hardly metabolized by CYP450 isoenzymes, which entails a lower probability of hepatic overload and, above all, drug interactions for patients with polypharmacy.

Furthermore, paliperidone ER more quickly dissociates from dopamine $\mathrm{D}_{2}$ receptors than risperidone, which may indicate a lower incidence of extrapyramidal side effects. Paliperidone binds at $a$-adrenergic receptors less than risperidone, though that does not rule out risk of orthostatic hypertension. Also, it binds less at $\mathrm{H}_{1}$ receptors than risperidone and does not block $5-\mathrm{HT}_{2 \mathrm{C}}$ receptors, so its propensity for weight increase is considered intermediate within its atypical class. Paliperidone seems to be the metabolite responsible for risperidoneinduced prolactin secretion, probably because it crosses the BBB to a lesser extent, and receptors on the tuberoinfundibular pathway are unprotected. Last, paliperidone ER can prolong the QTc interval, so it must be used with caution in patients who are predisposed to cardiac irregularity.

Finally, paliperidone's possible neuroprotective role could differentiate its pharmacodynamic profile from that of other antipsychotics, including risperidone.

\section{References}

1. López-Muñoz F, Alamo C, Rubio G, Cuenca E (2004) Half a century since the clinical introduction of chlorpromazine and the birth of modern psychopharmacology. Prog Neuropsychopharmacol Biol Psychiatry 28: 205208.

2. López-Muñoz F, Alamo C, Cuenca E, Shen WW, Clervoy P, et al. (2005) History of the discovery and clinical introduction of chlorpromazine. Ann Clin Psychiatry 17: 113-135.

3. Álamo C, López-Muñoz F, Bhatara VS, Cuenca E (2004) La contribución de la reserpina al desarrollo de la psiquiatría y su papel en la investigación neurobiológica. Rev Psiquiatr Fac Med Barc 31: 130-139.

4. Preskorn SH (2007) The evolution of antipsychotic drug therapy: reserpine chlorpromazine, and haloperidol. J Psychiatr Pract 13: 253-257.

5. Awouters FH, Lewi PJ (2007) Forty years of antipsychotic Drug research--from haloperidol to paliperidone--with Dr. Paul Janssen. Arzneimittelforschung 57 625-632.

6. López-Muñoz F, Alamo C (2009) The consolidation of neuroleptic therapy: Janssen, the discovery of haloperidol and its introduction into clinical practice. Brain Res Bull 79: 130-141.

7. Álamo C, López-Muñoz F, Cuenca E (1996) Algunos aspectos éticos en la prescripción de psicofármacos. Arch Neurobiol 59: 79-98.

8. López-Muñoz F, Alamo C, Cuenca E (1998) Fármacos antipsicóticos. In López-Muñoz F, Alamo C, eds., Historia de la Neuropsicofarmacología. Una nueva aportación a la terapéutica farmacológica de los trastornos del Sistema Nervioso Central, Ediciones Eurobook S.L., Madid 207-243.

9. Mitchell PB, Kirkby KC (2007) Las terapias biológicas antes de la introducción de los modernos psicofármacos. In López-Muñoz F, Alamo C, eds., Historia de la Psicofarmacología, Vol. II, La revolución de la psicofarmacología: sobre el descubrimiento y desarrollo de los psicofármacos, Editorial Médica Panamericana, S.A., Madrid 901-926.

10. Meyer JM, Leckband SG (2007) Antipsicóticos (IV) El desarrollo de la clozapina y su papel en la conceptualización de la atipicidad antipsicótica: antipsicóticos atípicos. In López-Muñoz F, Alamo C, eds., Historia de la Psicofarmacología Vol. II, La revolución de la psicofarmacología: sobre el descubrimiento y 
Citation: Álamo C, López-Muñoz F (2013) The Pharmacological Role and Clinical Applications of Antipsychotics' Active Metabolites: Paliperidone versus Risperidone. Clin Exp Pharmacol 3: 117. doi:10.4172/2161-1459.1000117

Page 10 of 12

desarrollo de los psicofármacos, Editorial Médica Panamericana, S.A., Madrid $669-680$

11. Hippius H (1999) A historical perspective of clozapine. J Clin Psychiatry 12: 22-23

12. Gründer G, Hippius H, Carlsson A (2009) The 'atypicality' of antipsychotics: a concept re-examined and re-defined. Nat Rev Drug Discov 8: 197-202.

13. Janssen Pa, Niemegeers Cj, Schellekens Kh (1965) Is It Possible To Predict The Clinical Effects Of Neuroleptic Drugs (Major Tranquillizers) From Animal Data?I. "Neuroleptic Activity Spectra" For Rats. Arzneimittelforschung 15: 104 117.

14. Sugerman Aa (1964) A Pilot Study Of Floropipamide (Dipiperon). Dis Nerv Syst 25: $355-358$

15. Meltzer HY, Lee MA, Ranjan R (1994) Recent advances in the pharmacotherapy of schizophrenia. Acta Psychiatr Scand Suppl 384: 95-101.

16. Álamo C, Cuenca E, López-Muñoz F (2004) Avances en psicofarmacología y perspectivas de futuro. In Avendaño MC, Tamargo J, eds., Nuevos avances en medicamentos, Real Academia Nacional de Farmacia, Madrid, 351-431.

17. Álamo C, Cuenca E, López-Muñoz F, García-García P (2007) Neurolépticos y Antipsicóticos. Aspectos farmacológicos de la evolución del tratamiento de la esquizofrenia. In Chinchilla A, ed., Nuevas Generaciones en Neurociencias. Las Esquizofrenias. Sus hechos y valores clínicos y terapéuticos, Elsevier Masson, Barcelona, 343-401.

18. López-Muñoz F, Álamo C (2011) Neurobiological background for the development of new drugs in schizophrenia. Clin Neuropharmacol 34: 111-126.

19. Spina E, Cavallaro R (2007) The pharmacology and safety of paliperidone extended-release in the treatment of schizophrenia. Expert Opin Drug Saf 6: $651-662$

20. Mauri MC, Volonteri LS, Colasanti A, et al. (2007) Clinical pharmacokinetics of atypical antipsychotics: A critical review of the relationship between plasma concentrations and clinical response. Clin Pharmacokin 46: 359-388.

21. Huang ML, Van Peer A, Woestenborghs R, De Coster R, Heykants J, et al. (1993) Pharmacokinetics of the novel antipsychotic agent risperidone and the prolactin response in healthy subjects. Clin Pharmacol Ther 54: 257-268.

22. Heykants J, Huang ML, Mannens G, Meuldermans W, Snoeck E, et al. (1994) The pharmacokinetics of risperidone in humans: a summary. J Clin Psychiatry 55 Suppl: 13-17.

23. de Leon J, Wynn G, Sandson NB (2010) The pharmacokinetics of paliperidone versus risperidone. Psychosomatics 51: 80-88.

24. Díez A, Pol E (2007) Paliperidona, un antipsicótico no tan nuevo y... ¿qué pasa con la hiperprolactinemia?. Rev Soc Esp Farm Comunit 2: 9-10.

25. Fang J, Bourin M, Baker GB (1999) Metabolism of risperidone to 9-hydroxyrisperidone by human cytochromes P450 2D6 and 3A4. Naunyn Schmiedebergs Arch Pharmacol 359: 147-151

26. Conley R, Gupta SK, Sathyan G (2006) Clinical spectrum of the osmoticcontrolled release oral delivery system (OROS), an advanced oral delivery form. Curr Med Res Opin 22: 1879-1892.

27. Lautenschlager M, Heinz A (2008) Paliperidone-ER: first atypical antipsychotic with oral extended release formulation. Expert Rev Neurother 8: 193-200.

28. Pani L, Pira L, Marchese G (2007) Antipsychotic efficacy: relationship to optima D2-receptor occupancy. Eur Psychiatry 22: 267-275.

29. Kapur S, Zipursky R, Jones C, Remington G, Houle S (2000) Relationship between dopamine $\mathrm{D}(2)$ occupancy, clinical response, and side effects: a double-blind PET study of first-episode schizophrenia. Am J Psychiatry 157: 514-520.

30. Álamo C, López-Muñoz F, Cuenca E (2003) Fármacos antipsicóticos. In Consejo General de Colegios Oficiales de Farmacéuticos de España, ed., Avances en Farmacología y Farmacoterapia, Mod. II, Avances en Farmacología del Sistema Nervioso, Acción Médica, S.A., Madrid 101-153.

31. Yang LP, Plosker GL (2007) Paliperidone extended release. CNS Drugs 21 417-425.

32. Tomlinson B (2008) A review of paliperidone ER: pharmacology and drug-drug interactions. CME Bull Aug: 16-17.

33. Yang MC, Lung FW (2011) Neuroprotection of paliperidone on SH-SY5Y cells against $\hat{~}^{2}$-amyloid peptide(25-35), $\mathrm{N}$-methyl-4-phenylpyridinium ion, and hydrogen peroxide-induced cell death. Psychopharmacology (Berl) 217: $397-$ 410

34. Cozza KL, Armstrong SC (2001) Concise guide to the cytochrome P450 system: Drug interaction principles for medical practice, American Psychiatric Publishing, Inc., Washington.

35. Sandson NB, Armstrong SC, Cozza KL (2005) An overview of psychotropic drug-drug interactions. Psychosomatics 46: 464-494.

36. Vermeir M, Naessens I, Remmerie B, Mannens G, Hendrickx J, et al. (2008) Absorption, metabolism, and excretion of paliperidone, a new monoaminergic antagonist, in humans. Drug Metab Dispos 36: 769-779.

37. Citrome $L$ (2010) Paliperidone palmitate - review of the efficacy, safety and cost of a new second-generation depot antipsychotic medication. Int J Clin Pract 64: $216-239$

38. Benítez J, LLerena A, Cobaleda J (1988) Debrisoquin oxidation polymorphism in a Spanish population. Clin Pharmacol Ther 44: 74-77.

39. Scordo MG, Spina E, Facciolà G, Avenoso A, Johansson I, et al. (1999) Cytochrome P450 2D6 genotype and steady state plasma levels of risperidone and 9-hydroxyrisperidone. Psychopharmacology (Berl) 147: 300-305.

40. Canuso CM, Youssef EA, Bossie CA, Turkoz I, Schreiner A, et al. (2008) Paliperidone extended-release tablets in schizophrenia patients previously treated with risperidone. Int Clin Psychopharmacol 23: 209-215.

41. Berwaerts J, Cleton A, Herben V, van de Vliet I, Chang I, et al. (2009) The effects of paroxetine on the pharmacokinetics of paliperidone extended-release tablets. Pharmacopsychiatry 42: 158-163.

42. Bondolfi G, Eap CB, Bertschy G, Zullino D, Vermeulen A, et al. (2002) The effect of fluoxetine on the pharmacokinetics and safety of risperidone in psychotic patients. Pharmacopsychiatry 35: 50-56.

43. Spina E, Avenoso A, Scordo MG, Ancione M, Madia A, et al. (2002) Inhibition of risperidone metabolism by fluoxetine in patients with schizophrenia: a clinically relevant pharmacokinetic drug interaction. J Clin Psychopharmacol 22: 419 423

44. Spina E, Avenoso A, Facciolà G, Scordo MG, Ancione M, et al. (2001) Plasma concentrations of risperidone and 9-hydroxyrisperidone during combined treatment with paroxetine. Ther Drug Monit 23: 223-227.

45. Saito M, Yasui-Furukori N, Nakagami T, Furukori H, Kaneko S (2005) Dosedependent interaction of paroxetine with risperidone in schizophrenic patients. J Clin Psychopharmacol 25: 527-532.

46. Tyson SC, Devane CL, Risch SC (1995) Pharmacokinetic interaction between risperidone and clozapine. Am J Psychiatry 152: 1401-1402.

47. Goff DC, Cather C, Evins AE, Henderson DC, Freudenreich O, et al. (2005) Medical morbidity and mortality in schizophrenia: guidelines for psychiatrists. $J$ Clin Psychiatry 66: 183-194.

48. Citrome L (2012) Oral paliperidone extended-release: chemistry pharmacodynamics, pharmacokinetics and metabolism, clinical efficacy, safety and tolerability. Expert Opin Drug Metab Toxicol 8: 873-888.

49. Boom S, Thyssen A, Crauwels H, Molz KH, Cleton A, et al. (2009) The influence of hepatic impairment on the pharmacokinetics of paliperidone. Int $J$ Clin Pharmacol Ther 47: 606-616.

50. Arakawa R, Ito H, Takano A, Takahashi H, Morimoto T, et al. (2008) Dosefinding study of paliperidone ER based on striatal and extrastriatal dopamine D2 receptor occupancy in patients with schizophrenia. Psychopharmacology (Berl) 197: 229-235.

51. Voicu VA, de Leon J, Medvedovici AV, RÄfdulescu FÅž, Miron DS (2012) New insights on the consequences of biotransformation processes on the distribution and pharmacodynamic profiles of some neuropsychotropic drugs. Eur Neuropsychopharmacol 22: 319-329.

52. Kelder J, Grootenhuis PD, Bayada DM, Delbressine LP, Ploemen JP (1999) Polar molecular surface as a dominating determinant for oral absorption and brain penetration of drugs. Pharm Res 16: 1514-1519.

53. Katritzky AR, Kuanar M, Slavov S, Dobchev DA, Fara DC, et al. (2006) Correlation of blood-brain penetration using structural descriptors. Bioorg Med Chem 14: 4888-4917.

54. Thiebaut F, Tsuruo T, Hamada H, Gottesman MM, Pastan I, et al. (1987) 
Citation: Álamo C, López-Muñoz F (2013) The Pharmacological Role and Clinical Applications of Antipsychotics' Active Metabolites: Paliperidone versus Risperidone. Clin Exp Pharmacol 3: 117. doi:10.4172/2161-1459.1000117

Page 11 of 12

Cellular localization of the multidrug-resistance gene product P-glycoprotein in normal human tissues. Proc Natl Acad Sci U S A 84: 7735-7738.

55. Thuerauf N, Fromm MF (2006) The role of the transporter P-glycoprotein for disposition and effects of centrally acting drugs and for the pathogenesis of CNS diseases. Eur Arch Psychiatry Clin Neurosci 256: 281-286.

56. Dean M, Rzhetsky A, Allikmets R (2001) The human ATP-binding cassette (ABC) transporter superfamily. Genome Res 11: 1156-1166.

57. Ambudkar SV, Kim IW, Sauna ZE (2006) The power of the pump: mechanisms of action of P-glycoprotein (ABCB1). Eur J Pharm Sci 27: 392-400.

58. Lin JH (2003) Drug-drug interaction mediated by inhibition and induction of P-glycoprotein. Adv Drug Deliv Rev 55: 53-81.

59. Schinkel AH (1999) P-Glycoprotein, a gatekeeper in the blood-brain barrier. Adv Drug Deliv Rev 36: 179-194.

60. Schinkel AH, Jonker JW (2003) Mammalian drug efflux transporters of the ATP binding cassette (ABC) family: an overview. Adv Drug Deliv Rev 55: 3-29.

61. Linnet K, Ejsing TB (2008) A review on the impact of P-glycoprotein on the penetration of drugs into the brain. Focus on psychotropic drugs. Eur Neuropsychopharmacol 18: 157-169.

62. Ejsing TB, Pedersen AD, Linnet K (2005) P-glycoprotein interaction with risperidone and 9-OH-risperidone studied in vitro, in knock-out mice and in drug-drug interaction experiments. Hum Psychopharmacol 20: 493-500.

63. Wang JS, Ruan Y, Taylor RM, Donovan JL, Markowitz JS, et al. (2004) The brain entry of risperidone and 9-hydroxyrisperidone is greatly limited by P-glycoprotein. Int J Neuropsychopharmacol 7: 415-419.

64. Zhu HJ, Wang JS, Markowitz JS, Donovan JL, Gibson BB, et al. (2007) Risperidone and paliperidone inhibit p-glycoprotein activity in vitro. Neuropsychopharmacology 32: 757-764.

65. Cada DJ, Baker DE, Levien T (2007) Paliperidone. Hosp Pharm 42: 637-647.

66. Spina E, Crupi R (2011) Safety and Efficacy of Paliperidone Extended-Release in Acute and Maintenance Treatment of Schizophrenia. J Central Nerv Syst Dis 3: $27-41$

67. Thyssen A, Cleton A, Talluri K, Leempoels J, Janssens L, et al. (2009) No pharmacokinetic interaction between paliperidone extended-release tablets and trimethoprim in healthy subjects. Hum Psychopharmacol 24: 532-539.

68. López-Muñoz F, Álamo C, Cuenca E (2005) Historia de la Psicofarmacología. In Vallejo J, Leal C, dirs., Tratado de Psiquiatría, Vol. II. Ars Médica, Barcelona 1709-1736.

69. Remington G, Kapur S (1999) D2 and 5-HT2 receptor effects of antipsychotics: bridging basic and clinical findings using PET. J Clin Psychiatry 60 Suppl 10: 15-19.

70. Schotte A, Janssen PF, Gommeren W, Luyten WH, Van Gompel P, et al (1996) Risperidone compared with new and reference antipsychotic drugs: in vitro and in vivo receptor binding. Psychopharmacology (Berl) 124: 57-73.

71. Schotte A, Bonaventure P, Janssen PF, Leysen JE (1995) In vitro receptor binding and in vivo receptor occupancy in rat and guinea pig brain: risperidone compared with antipsychotics hitherto used. Jpn J Pharmacol 69: 399-412.

72. Richelson E, Souder T (2000) Binding of antipsychotic drugs to human brain receptors focus on newer generation compounds. Life Sci 68: 29-39.

73. Nyberg S, Eriksson B, Oxenstierna G, Halldin C, Farde L (1999) Suggested minimal effective dose of risperidone based on PET-measured D2 and 5-HT2A receptor occupancy in schizophrenic patients. Am J Psychiatry 156: 869-875.

74. Yasuno F, Suhara T, Okubo Y, Sudo Y, Inoue M, et al. (2001) Dose relationship of limbic-cortical D2-dopamine receptor occupancy with risperidone. Psychopharmacology (Berl) 154: 112-114.

75. Ereshefsky L, Mascarenas CA (2003) Comparison of the effects of different routes of antipsychotic administration on pharmacokinetics and pharmacodynamics. J Clin Psychiatry 64 Suppl 16: 18-23.

76. Seeman $P$ (2005) An update of fast-off dopamine D2 atypical antipsychotics. Am J Psychiatry 162: 1984-1985.

77. Ezewuzie N, Taylor D (2006) Establishing a dose-response relationship for oral risperidone in relapsed schizophrenia. J Psychopharmacol 20: 86-90.

78. Yoshimura R, Ueda N, Ikenouch-Sugita A, et al. (2009) Fluctuating plasma levels of the active moiety of risperidone is related to occurrence of extrapyramidal symptoms. Int J Psychiatry Clin Pract 13: 21-23.

79. Dursun S (2005) An atypical long-acting injectable antipsychotic: implications for pharmacotherapy of schizophrenia. J Psychopharmacol 19: 3-4.

80. Karlsson P, Dencker E, Nyberg S, et al. (2006) Pharmacokinetics, dopamine D2 and serotonin 5-HT2A receptor occupancy and safety profile of paliperidone extended-release in healthy subjects. Schizophr Res 81: 85e6.

81. Karlsson P, Dencker E, Nyberg S, et al. (2005) Pharmacokinetics and dopamine D2 and serotonin 5-HT2A receptor occupancy of paliperidone in healthy subjects. Eur Neuropsychopharmacol 15: S385.

82. Davidson M, Emsley R, Kramer M, et al. (2006) Efficacy, safety and effect on functioning of paliperidone extended release tablets in the treatment of acute schizophrenia: an international 6-week placebo-controlled study. Schizophr Res 81: 43.

83. Meltzer HY, Bobo WV, Nuamah IF, Lane R, Hough D, et al. (2008) Efficacy and tolerability of oral paliperidone extended-release tablets in the treatment of acute schizophrenia: pooled data from three 6-week, placebo-controlled studies. J Clin Psychiatry 69: 817-829.

84. Davidson M, Emsley R, Kramer M, Ford L, Pan G, et al. (2007) Efficacy, safety and early response of paliperidone extended-release tablets (paliperidone ER) results of a 6-week, randomized, placebo-controlled study. Schizophr Res 93 117-130.

85. Emsley R, Berwaerts J, Eerdekens M, Kramer M, Lane R, et al. (2008) Efficacy and safety of oral paliperidone extended-release tablets in the treatment of acute schizophrenia: pooled data from three 52-week open-label studies. Int Clin Psychopharmacol 23: 343-356.

86. Tzimos A, Samokhvalov V, Kramer M, Ford L, Gassmann-Mayer C, et al. (2008) Safety and tolerability of oral paliperidone extended-release tablets in elderly patients with schizophrenia: a double-blind, placebo-controlled study with six-month open-label extension. Am J Geriatr Psychiatry 16: 31-43.

87. Eberhard J, Lindström E, Holstad M, Levander S (2007) Prolactin level during 5 years of risperidone treatment in patients with psychotic disorders. Acta Psychiatr Scand 115: 268-276.

88. Duval F, Guillon MS, Mokrani MC, Crocq MA, Garcia Duarte F (2008) Relationship between prolactin secretion, and plasma risperidone and 9-hydroxyrisperidone concentrations in adolescents with schizophreniform disorder. Psychoneuroendocrinology 33: 255-259.

89. Knegtering R, Baselmans P, Castelein S, Bosker F, Bruggeman R, et al. (2005) Predominant role of the 9-hydroxy metabolite of risperidone in elevating blood prolactin levels. Am J Psychiatry 162: 1010-1012.

90. Melkersson KI (2006) Prolactin elevation of the antipsychotic risperidone is predominantly related to its 9-hydroxy metabolite. Hum Psychopharmacol 21 529-532.

91. Berwaerts J, Cleton A, Rossenu S, Talluri K, Remmerie B, et al. (2010) A comparison of serum prolactin concentrations after administration of paliperidone extended-release and risperidone tablets in patients with schizophrenia. J Psychopharmacol 24: 1011-1018.

92. Wieck A, Haddad PM (2003) Antipsychotic-induced hyperprolactinaemia in women: pathophysiology, severity and consequences. Selective literature review. Br J Psychiatry 182: 199-204.

93. Kapur S, Seeman P (2000) Antipsychotic agents differ in how fast they come off the dopamine D2 receptors. Implications for atypical antipsychotic action. J Psychiatry Neurosci 25: 161-166.

94. Kapur S, Seeman P (2001) Does fast dissociation from the dopamine d(2) receptor explain the action of atypical antipsychotics?: A new hypothesis. Am J Psychiatry 158: 360-369.

95. Álamo C, López-Muñoz F, Cuenca E (2002) Farmacología de los agentes antipsicóticos. In Rubio G, Hernández JA, Jiménez-Arriero MA, Palomo T, eds., Guía para el tratamiento de los pacientes con esquizofrenia. Fundación Cerebro y Mente, Madrid 123-146.

96. Janssen PA, Niemegeers CJ, Awouters F, Schellekens KH, Megens AA, et al. (1988) Pharmacology of risperidone (R 64 766), a new antipsychotic with serotonin-S2 and dopamine-D2 antagonistic properties. J Pharmacol Exp Ther 244: 685-693.

97. Meltzer HY, Matsubara S, Lee JC (1989) Classification of typical and atypical 
Citation: Álamo C, López-Muñoz F (2013) The Pharmacological Role and Clinical Applications of Antipsychotics' Active Metabolites: Paliperidone versus Risperidone. Clin Exp Pharmacol 3: 117. doi:10.4172/2161-1459.1000117

Page 12 of 12

antipsychotic drugs on the basis of dopamine D-1, D-2 and serotonin2 pKi values. J Pharmacol Exp Ther 251: 238-246.

98. Remington G (2008) Alterations of dopamine and serotonin transmission in schizophrenia. Prog Brain Res 172: 117-140

99. Stahl SM (2003) Describing an atypical antipsychotic: Receptor Binding and its role in the pathophysiology. Prim Care Comp J Clin Psychiatr 5: 9-13.

100. Miyamoto S, Duncan GE, Marx CE, Lieberman JA (2005) Treatments for schizophrenia: a critical review of pharmacology and mechanisms of action of antipsychotic drugs. Mol Psychiatry 10: 79-104

101. Miyamoto S, Miyake N, Jarskog LF, Fleischhacker WW, Lieberman JA (2012) Pharmacological treatment of schizophrenia: a critical review of the pharmacology and clinical effects of current and future therapeutic agents. Mol Psychiatry 17: 1206-1227.

102.Emsley RA (1999) Risperidone in the treatment of first-episode psychotic patients: a double-blind multicenter study. Risperidone Working Group. Schizophr Bull 25: 721-729.

103. Álamo C, Cuenca E, López-Muñoz F (2007) Farmacología básica de los antipsicóticos. Mecanismos de acción implicados en efectos terapéuticos y adversos. In Gasto C, ed., Esquizofrenia y trastornos afectivos, Editorial Médica Panamericana, S.A., Madrid 63-75.

104.Kapur S, Zipursky RB, Remington G, Jones C, DaSilva J, et al. (1998) 5-HT2 and D2 receptor occupancy of olanzapine in schizophrenia: a PET investigation. Am J Psychiatry 155: 921-928.

105. Kapur S, Zipursky RB, Remington G (1999) Clinical and theoretical implications of 5-HT2 and D2 receptor occupancy of clozapine, risperidone, and olanzapine in schizophrenia. Am J Psychiatry 156: 286-293.

106. Gefvert $O$, Lundberg $T$, Wieselgren IM, Bergström $M$, Långström $B$, et al. (2001) D(2) and 5HT(2A) receptor occupancy of different doses of quetiapine in schizophrenia: a PET study. Eur Neuropsychopharmacol 11: 105-110.

107. Moresco RM, Cavallaro R, Messa C, Bravi D, Gobbo C, et al. (2004) Cerebral D2 and 5-HT2 receptor occupancy in Schizophrenic patients treated with olanzapine or clozapine. J Psychopharmacol 18: 355-365.

108. Mamo D, Kapur S, Shammi CM, Papatheodorou G, Mann S, et al. (2004) A PET study of dopamine D2 and serotonin 5-HT2 receptor occupancy in patients with schizophrenia treated with therapeutic doses of ziprasidone. Am J Psychiatry 161: 818-825.

109. Farde L, Nordström AL, Wiesel FA, Pauli S, Halldin C, et al. (1992) Positron emission tomographic analysis of central D1 and D2 dopamine receptor occupancy in patients treated with classical neuroleptics and clozapine. Relation to extrapyramidal side effects. Arch Gen Psychiatry 49: 538-544.

110. Gahr M, Kölle MA, Schönfeldt-Lecuona C, Lepping P, Freudenmann RW (2011) Paliperidone extended-release: does it have a place in antipsychotic therapy? Drug Des Devel Ther 5: 125-146.

111. Kim DH, Maneen MJ, Stahl SM (2009) Building a better antipsychotic: receptor targets for the treatment of multiple symptom dimensions of schizophrenia. Neurotherapeutics 6: 78-85.

112. Cutler A, Ball S, Stahl SM (2008) Dosing atypical antipsychotics. CNS Spectr 13: 1-16.
113. Reynolds GP, Zhang ZJ, Zhang XB (2002) Association of antipsychotic druginduced weight gain with a 5 -HT2C receptor gene polymorphism. Lancet 359 : 2086-2087.

114. Matsui-Sakata A, Ohtani H, Sawada Y (2005) Receptor occupancy-based analysis of the contributions of various receptors to antipsychotics-induced weight gain and diabetes mellitus. Drug Metab Pharmacokinet 20: 368-378.

115. de Leon J, Correa JC, Ruaño G, Windemuth A, Arranz MJ, et al. (2008) Exploring genetic variations that may be associated with the direct effects of some antipsychotics on lipid levels. Schizophr Res 98: 40-46.

116. Harrison-Woolrych M, Garcia-Quiroga J, Ashton J, Herbison P (2007) Safety and usage of atypical antipsychotic medicines in children: a nationwide prospective cohort study. Drug Saf 30: 569-579.

117. Marino J, Caballero J (2008) Paliperidone extended-release for the treatment of schizophrenia. Pharmacotherapy 28: 1283-1298.

118. Wang SM, Han C, Lee SJ, Patkar AA, Pae CU, et al. (2012) Paliperidone: a review of clinical trial data and clinical implications. Clin Drug Investig 32 497-512.

119. Citrome L (2007) Paliperidone: quo vadis? Int J Clin Pract 61: 653-662.

120. Lieberman JA, Stroup TS, McEvoy JP, Swartz MS, Rosenheck RA, et al. (2005) Effectiveness of antipsychotic drugs in patients with chronic schizophrenia. N Engl J Med 353: 1209-1223

121. Gil-ad I, Shtaif B, Shiloh R, Weizman A (2001) Evaluation of the neurotoxic activity of typical and atypical neuroleptics: relevance to iatrogenic extrapyramidal symptoms. Cell Mol Neurobiol 21: 705-716.

122. Galili R, Mosberg, Gil-Ad I, Weizman A, Melamed E, et al. (2000) Haloperidolinduced neurotoxicity--possible implications for tardive dyskinesia. J Neural Transm 107: 479-490.

123. Noh JS, Kang HJ, Kim EY, Sohn S, Chung YK, et al. (2000) Haloperidolinduced neuronal apoptosis: role of p38 and c-Jun- $\mathrm{NH}(2)$-terminal protein kinase. J Neurochem 75: 2327-2334.

124. Gassó P, Mas S, Molina O, Bernardo M, Lafuente A, et al. (2012) Neurotoxic/ neuroprotective activity of haloperidol, risperidone and paliperidone in neuroblastoma cells. Prog Neuropsychopharmacol Biol Psychiatry 36: 71-77.

125. Behl C, Rupprecht R, Skutella T, Holsboer F (1995) Haloperidol-induced cell death--mechanism and protection with vitamin $E$ in vitro. Neuroreport 7: 360364.

126. Bai O, Wei Z, Lu W, Bowen R, Keegan D, et al. (2002) Protective effects of atypical antipsychotic drugs on PC12 cells after serum withdrawal. J Neurosci Res 69: 278-283.

127. Corena-McLeod MP, Oliveros A, Charlesworth C, et al. (2008) Paliperidone as a mood stabilizer: a pre-frontal cortex synaptoneurosomal proteomics comparison with lithium and valproic acid after chronic treatment reveals similarities in protein expression. Brain Res 1233: 8-19.

128. Schmidt AJ, Krieg JC, Clement HW, Hemmeter UM, Schulz E, et al. (2010) Effects of quetiapine, risperidone, 9-hydroxyrisperidone and ziprasidone on the survival of human neuronal and immune cells in vitro. J Psychopharmacol 24: 349-354. 